\title{
Code Mixing and Code Switching in Contemporary Indonesia Dangdut Music: A Sociolinguistic Case of Nela Kharisma Song Lyrics
}

\author{
Sri Hesti Heriwati \\ Indonesia Institute of the Arts Surakarta
}

\begin{abstract}
Language was basically a medium for describing ideas as well as when singers singing their songs by using language. But listening to Nella Kharisma's song lyrics were very interesting because the songs used many phrases that were translated into other languages and used code mixing in the lyrics of the songs. Language, in the view of sociolinguistics contained different variations. A sociolinguist explained the correlation between variations with social and situational factors. This situation affected the language used by musicians whom at any time incorporated linguistic elements outside of their native language. Due to the variety of language usage, what had come to be called bilingual users has emerged. Sociolinguistics as a branch of linguistics viewed or placed language position in relation to language using. The tendency in switching between languages using due to the changing of situations was called code switching.

The discussion of code switching was usually followed by code mixing, which was about the existence of a basic code that was used and had autonomous functions. A speaker who had mastered more than one language would have the opportunity to mix codes. But that did not mean that speakers who mastered more languages always mix more codes. A speaker who slipped a lot of other languages into the language he was using was called code mixing. The background of code mixing and code switching could be seen from the mixed language of a person/figure using more than one language. Specific characteristics of speakers would influence the code mixing.

This discussion became very interesting when looking at the lyrics of the songs sung by Nella Kharisma and looking at them from sociolinguistic parameters. This paper would talk about the problem of switching from one language to another, using sociolinguistic approaches method and linguistic analysis method. The results achieved were to find out how far the language was used by Nella Kharisma in the lyrics of the song she sang.
\end{abstract}

Keywords: song lyrics, code switching, code mixing, Indonesia dangdut

DOI: $10.7176 /$ JLLL/54-09

Publication date:March $31^{\text {st }} 2019$

\section{Prologue}

Language and language exertions were always influenced by linguistic and nonlinguistic factors. Nonlinguistic factors included social factors, and situational factors. Social factors that influenced language utilizations, for example: social status, education level, age, economic level, gender. Situational factors that had an impact on the language use were found in who speaks, in what language, to whom, when, where, and about what problems (Suwito, 2011: 3). It was this situational factor that caused language variations. Halliday in Pateda, 1987; Alwasilah, 1993 described that variations in language were used based on usage (style) and variation based on usage (dialect). Furthermore, language variations were language forms, each of which had a pattern that resembles the general pattern of its parent language. A form of language variation (see: Maryono, 1998) was an idiolect, dialect, variety, register, and undho usuk (language stratification). Events of variation in the domain, racial, even occured in the use of individual languages. In relation to language usage, there were variations in language. The language variations here would address the problem of using language in Nella Kharisma's song lyrics as a limitation of problems.

Limitation of problem was intended to insert and issue information that had just been obtained in the field, determining focus, simplifying the decisions making process about which data did not need to be touched or which data would be discarded (Moleong, 2016). This paper meant to discuss song lyrics, focusing more on lyrics application. The problem in this writing was how the form of code switching and code mixing was applied to Nella Kharisma's song lyrics. Nella Kharisma was a famous dangdut music singer in Indonesia.

Nella Kharisma was born and raised in Kediri, East Java, Indonesia. She was a dangdut singer who began her career in 2015 from stage to stage with the Monata music group. Nella Kharisma was increasingly popular and 
was loved by people who liked dangdut koplo music. Although she was indeed not as famous as other singers from Jakarta, but Nella Kharisma's schedule was full. She was often invited to be a guest star at several events such as weddings, circumcisions, thanksgivings, birthdays, and others. In early 2017 Nella Kharisma joined a record company from Bintaro, South Tangerang, namely Pancal Records Indonesia. In collaboration with the record company, she released her album titled Goyang Reggae, Stop Bimbang, and Indonesia Sehat, along with singers Ratna Antika and Sodiq Monata. In addition to joining Pancal Records Indonesia, currently Nella Kharisma also joined other record companies, such as DSA Records, Samudra Records, and Khatulistiwa Record.

The samples used in this paper were some of the lyrics sung by Nella Kharisma, which were chosen because they contained elements of code switching and code mixing events. The technique used in data collection was document recording (content analysis), a technique used to deduce data in identifying scripts sourced from the lyrics. After recording all the events, the data collection technique was conducted with the model: listening and recording techniques. It meant conducting verbal language spontaneously and recording data that were relevant and in accordance with the goals and objectives of writing. Data samples were contained in songs entitled Sayang, Jaran Goyang, Bojoku Galak, Ditinggal Rabi, and Sayang 2, which were considered to contain code mixing and code switching.

\section{Code, code switching, and code mixing in sociolinguistics}

Theoretical study was intended to support the theoretical and conceptual framework as a basis that could be accounted for. The theories related to this writing included theories that addressed the problem of code mixing and code switching. Code switching was an event of language change from casual variety to official variety, or also official variety to casual variety (Chaer 2010: 107). Appel defined code switching as a symptom of switching language usage because of changing circumstances. Hymes stated that code switching did not only occur between languages, but could occur between various types or styles contained in one language. Multilingual society was very difficult when a speaker used only one language. In code switching each language still tended to support each function and the function according to the context. Mixed code was the use of two languages or more or two variants of a language in a community. A main code or basic code was used and had a function and autonomy while the other code involved in the speech event was only pieces without the autonomous function as a code (Chaer 2010: 107).

Harimurti Kridalaksana (2013) explained that sociolinguistics was a branch of linguistics that studied the correlation and mutual influence between language behaviour and social behaviour. Sociolinguistics could be formulated as a study of language and language usage in relation to society and culture (Gumperz, 1971 in Soewito, 2011: 5). It was said that sociolinguistics was interdisciplinary studies that dealt with linguistic problems in relation to social problems.

Code could be interpreted as a language system used by human. The use of language was adjusted to the background of the speaker and the speaker's relation with the partner. The speaker background included his social background. When someone talked, he actually sent the codes to his partner, this encoding was through a process (see: Wijana 2013) which occurred both to speakers and to his speaking partners. These codes were naturally produced by human speech tools so that any sound changes resulted in a change of meaning. In relation to existing problems, the emphasis would be more on code mixing and code switching in lyrics using (see Nababan, 2011).

\section{Code Mixing and Code Switching in Nella Kharisma's Song Lyrics}

Code mixing and code switching analysis was one of short paper results that were able to raise some grammatical problems with sociolinguistic dimensions. Some problems provided opportunities, as well as attracted other experts to research and revealed other similar problems so as to open the awareness of the importance of linguists in having socio-cultural insights when looking at existing problems. The grammatical problems that would be raised here included Code Mixing and Code Switching.

Code Mixing was language unit using from one language to another in order to expand the style of language or variety of languages, including the use of words, clauses, idioms, greetings, etc. (Harimurti Kridalaksana, 2013: 35). Code mixing occurred because of the reciprocal relations between the role (speaker) of the language formats and language functions. This meant that someone who had particular social background tended to have a certain form of code mixing. Thus code mixing occurred smoothly and mutual understanding could occur.

The informal situation above explained that code mixing would often occur in informal or casual conversations 
or speech events. In situations like this speakers would be freer in choosing the language code used in expressing their messages, supported also by the presence of spontaneous nature in its delivery.

The kinds of code mixing could be seen in various events, namely:

a. The insertion of elements that were in the form of words was a standalone language unit, and consisted of a single morpheme or a combination of morphemes. For example on the song "Sayang-2"

andaikan sayangku sak iki isih ono ning kene

kita akan selalu memadu cinta

bungah ing atiku sepi ing atiku

hanya dalam mimpi

rino lan wengi moto iki angel diaremake

mung lam-laman esem lan manismu

kapan ku bertemu sak kedip ing moto

(suppose my lover is still here right now

we will always make love

happy heart, my heart is lonely

only in dream

Day and night, my eyes are hard to close

because I always imagine your sweet smile

when can I meet, even if only in the blink of an eye)

$\ldots$

Language elements that indicate code mixing events between language texts. This could be observed in the choice of words taken in Indonesian and Javanese. Basically, in this case it could be said that sociolinguistics had included elements of Javanese and Indonesian. Code mixing could be identified by seeing code switching from Indonesian to Javanese. This could be seen in the lyrics " andaikan sayangku sak iki isih ono ning kene (if my love is still here now)". The use of the lyrics from the phrase 'andaikan sayangku (if only my love' then switched to the use of the Javanese language 'sak iki isih ono kene (is still here now)'. It was clear that the use of this phrase was categorized as code switching from Indonesian into Javanese.

The text that said 'kita akan selalu memadu cinta (we will always make love)', was another thing that could be observed in a lyric entitled "Sayang - 2". "Bungah ing atiku sepi ing atiku, hanya dalam mimpi" (the phrase 'hanya dalam mimpi (only in my dream)' was connected with the next phrase, but using Javanese, the phrase 'rino lan wengi moto iki angel diaremake (days and nights my eyes are hard to close)'). Then the phrase 'mung lam-laman esem lan manismu (because I always imagine your sweet smile)' was connected with the use of Indonesian 'kapan ku bertemu sak kedip ing moto'. 'Kapan ku bertemu' phrase could be understood by everyone, but when the phrase was connected with the phrase 'sak kedip ing moto' (a blink of an eye / just for a moment) the meaning of this Javanese word was not generally known. It could be said that almost all of Nella Kharisma's song lyrics used the transition from Indonesian to Javanese.

b. The process of inserting elements in the form of phrases (a combination of words or more that were not predicative), the combination of words could be tight and could be tenuous. For example on the song "Ditinggal Rabi (left to marry someone else)"

Kowe tego nglarani blenjani janji suci...

(You have the heart to hurt me, deny the holy promise)

The next example of code mixing could be seen in the insertion of some phrases. This could be found in the use of phrase 'janji suci (holy promise)'. The word 'suci (holy)' was mixed with the word 'janji (promise)', which was combined with the word mblenjani (to deny). "Kowe Tego Nglarani Blenjani Janji Suci" (You have the heart to hurt me, deny the holy promise). This can be observed in the Javanese phrase 'kowe tego nglarani blenjani', which then turned to the Indonesian phrase 'janji suci (holy promise)'.

c. Elements insertion in the form of words repetition. Words repetition was a word produced by the 
reduplication process. Another thing that could be observed was in the lyrics: sungguh keterlaluan bojoku sing saiki (it is really outrageous, my recent husband), the use of Indonesian language mixed with Javanese language, bojoku sing saiki (my current husband)'. In the lyric 'ngerasake bojoku sing ra tau perhatian' (I experienced having a husband who was never attentive), was switched from Javanese into Indonesian. Lyrics in: Dan dudidam aku padamu 'saya padamu' (Dam dudidam I am into you 'I am to you'), I love you, cukup siji solusinya (I love you there is only one way oout)', Pergi ke dukun (go visit a shaman), Ndang dicubo, mesthi kasil terbukti kasiate, genjrot (Quick, let's try it, it must be efficacious, gejrot)'. When it was observed, the lyrics used a lot of Javanese, Indonesian, and even English. For example on the song "Bojo Galak (Angry Husband)"

\section{ngerasake bojoku sing ra tau perhatian \\ mungkin wes dadi jodone \\ sungguh keterlaluan bojoku sing saiki \\ di matamu aku iki ora tau bener}

(This is what it feels like to have a husband who never pays attention

Maybe he really is my soul mate

it's really outrageous, my current husband

in your eyes I have never been right)

The code mixing cases occurred in the insertion of repetitive words elements were found in phrases such as in 'bojoku' and 'bojoku'. The use of 'Semar mesem, Semar mesem, Semar mesem' (smiling Semar, smiling Semar, smiling Semar) as an indicator of the form of repetition, was classified into the use of code mixing containing the reduplication process.

The song Jaran Goyang (Rocking Horse) (2018) used a mixture of languages, ranging from Javanese, mixed with Indonesian, and also using English. Check the following lyrics. There was a coded transition from the Javanese language then switched to the word 'perhatian (attention)' (This is what it feels like to have a husband who never pays attention). Thus the word 'mungkin (maybe)' was a vocabulary in Indonesian, but connected with the use of the Javanese word 'mungkin jodone (maybe it's a mate)', sungguh keterlaluan bojoku sing saiki (it was really outrageous my current husband)'. the phrase 'di matamu aku (in your eyes, I)' used Indonesian then switched to Javanese language: iki ora tau bener (have never been right)'.

Code mixing that was inserted in the form of expressions or idioms, contained in the lyrics that used foreign words. These foreign words were treated as idioms, then inserted between local language lyrics. The lyrics of the song titled "Sayang" included the phrase " Meh sambat kaleh sinten nyen sampun mekaten (to whom I will complain when this is done)' and'"Merana uripku (my life is miserable) '. The word' 'merana (miserable, Ind)' was connected with the word 'uripku (my life, Jv)' which was Javanese.

Code switching by speaker by changing the topic from problem one to another problem was what was called code switching (Rene Apple in Pateda, 2015: 85). The type of code switching could be in the form of variant switching, variety switching, and style switching. In code switching using two or more languages, it was characterized by: (a) each language still supported its own functions according to its context; (b) the function of each language was tailored to the situation relevant to the changing context.

Code switching was known, especially in community groups that were bilingual, but this process could actually occur from one language variation to another. In a bilingual society, code switching that occurred from one language that was used had meaning in accordance with the meaning of the code being addressed. Code switching did not run arbitrarily but there was a meaning that corresponded to the direction of code switching and the meaning of each code. In general, people changed code from one code to another that could not be done carelessly. The process must follow certain patterns.

Code switching was a language event caused by factors outside of the language itself, especially factors that were socio-situational.

\section{Conclusion}

The observation of code mixing and code switching using in the making of Nella Kharisma song lyrics, it could be stated that the use of language could lead to a variety of languages. Sociolinguistic studies could look at 
language using in the text. This would facilitate the process of language using with code mixing and code switching nuances. Having a high education background would have an impact on the words choice, by language code mixing, both from Indonesian, English, or other languages. Likewise in language coding, there was a change in the use of word variants from Javanese to Indonesian or vice versa, from the use of Indonesian to Javanese. In addition there were also word variants from Javanese and English. The results showed that Nella Kharisma's song lyrics used a lot of code switching from Javanese to Indonesian and English. As for the code mixing, Nella Kharisma used a combination of Javanese and Indonesian.

\section{Bibliography}

Abdul Chaer. 2014.. Sosiolinguistik. Jakarta:Rineka Cipta

Chaedar Alwasilah.1993. Sosiologi Bahasa. Bandung: Angkasa

Dewa Putu Wijana. 2013. Sosiolinguistik. Yogyakarta: Pustaka Pelajar

Gumperz, John J. 1971. Language in Social Groups. Standford, California: Inversity Press

Mansoer Pateda. 2015. Sosiolinguistik. Bandung: Angkasa

Maryono Dwi Raharjo, “Sosiolinguistik: Konsep Dasar dan Peranannya” Mibas, No. 19/th.IX/1988-hal 72

Moleong, Lexy J. 2016 Metode Penelitian Kualitatif. Bandung: Remaja Karya

Nababan, PWJ, 2011. Sosiolinguistik. Jakarta: Gramedia

Sutopo, HB. 2014. Metodologi Penelitian Kualitatif. Kumpulan makalah: Dosen Universitas Muhammadiyah Surakarta

Soewito, 2011. Sosiolinguistik. Surakarta: Henary Offset 